\title{
The Effectiveness of Mobile Augmented Reality Assisted STEM-Based Learning on Scientific Literacy and Students' Achievement
}

\author{
Yuliana Wahyu \\ Universitas Katolik Indonesia Santu Paulus Ruteng, Indonesia, \\ yulianawahyu76@gmail.com
}

I Wayan Suastra

Prof., Universitas Pendidikan Ganesha, Indonesia, i_wayansuastra@yahoo.com

I Wayan Sadia

Prof., Universitas Pendidikan Ganesha, Indonesia,wayan.sadia@undiksha.ac.id

\section{Ni Ketut Suarni}

Prof., Universitas Pendidikan Ganesha, Indonesia, niketut.suarni@undiksha.ac.id

\begin{abstract}
This study aims at describing the effectiveness of Mobile Augmented Reality (MAR) Assisted STEM-Based Learning on Scientific Literacy and Students' Achievement. This Quasi-Experimental research employed posttest-only control group design. It was conducted at the fourth-grade students of the Elementary School Teacher Program of Saint Paul Educational College Ruteng, Indonesia. The sample was taken using a random sampling technique from the intake classes, which consists of three parallel classes. Then, the students from class A and B was treated as an experimental group, and two other classes (class $\mathrm{C}$ and D) were considered as the control group. The experiment group students were taught using MAR Assisted STEM-Based learning, while the control group, students were taught applying a conventional method of learning. In collecting the data, the study employed a science achievement test and a scientific literacy test. The results revealed that: 1) The application of STEM-based learning assisted by Mobile Augmented Reality is quite effective in increasing students' scientific literacy. 2) The application of STEM-based learning assisted by Mobile Augmented Reality is effective in improving students' achievement. 3) There is a difference in the results of the students' scientific literacy and achievement between the students who are taught using STEM-based learning assisted by mobile augmented reality and students who are taught applying conventional learning.
\end{abstract}

Keywords: science achievement, scientific literacy, STEM, MAR, science, technology

Citation: Wahyu, Y., Suastra, I. W., Sadia, I. W., \& Suarni, N. K. (2020). The Effectiveness of Mobile Augmented Reality Assisted STEM-Based Learning on Scientific Literacy and Students' Achievement. International Journal of Instruction, 13(3), 343-356. https://doi.org/10.29333/iji.2020.13324a 


\section{INTRODUCTION}

The mastery of science and technology is an important key in facing educational challenges in the $21^{\text {st }}$ century. Based on this thinking, science education as part of education plays an important role in preparing students to have scientific literacy (Permanasari, 2016). What is science? Terminologically, science is a way of thinking, of investigating, a body of knowledge (Chiappetta \& Collette, 1994), whereas literacy consists of the word literatus and Scientia. Literatus means literacy, and Scientia means science (Echols \& Shadily, 2002). Therefore, scientific literacy is the ability to read, write, and communicate the scientific topics and socio-scientific issues related to culture and understanding of individual students in daily life and understanding procedures in developing new knowledge in the fields of science and technology (Greehow et al., 2015). Science literacy is critical to be prepared because everybody needs information in daily life as a reference to think scientifically in making decisions and solving problems (Ardianto \& Rubini, 2018). Functional scientific literacy cannot be separated from excellent scientific achievement. Learning achievement is an actual ability that can be directly measured through the test (Mahendra, 2007). Good scientific learning outcomes are inseparable from effective and meaningful science learning approaches, strategies, and learning methods during the scientific learning process in class. Susanto (Marguna et al., 2018) stated that the problem in education is a weakness in the implementation of the teaching and learning process by teachers at schools. Science education is taught as the basis for the formation of students' scientific literacy to improve the results of learning science. The science learning process should be the active learning process where teachers are acting as managers of learning that can select and decide the suitable strategy, which is appropriate with the students' characteristics, material characteristics, instrumental factor, and learning environment (Suastra, 2009). A professional science teacher is expected to lead students to explore science and technology in this competitive globalization era. Therefore, meaningful science learning can empower the student's scientific literacy and achievement; and to prepare professional teacher candidates in a science subject at elementary education.

Science learning does not only cover scientific concepts or scientific theories but also includes the science process taught through the practicum. But even this is rarely done by teachers because there is no specific time for practicum, inadequate facilities, and solid material. Though science practicum holds an important role in the process of learning science (Adisendjaja \& Romlah, 2009), obstacles in practicum can be overcome by using alternative learning media in the form of mobile augmented reality. Mobile Augmented reality is a form of the merging of visualization between the real and virtual worlds that can enhance the user's view of the real world with computergenerated elements in 2 dimensions and text (Boyles, 2017). Research on the use of STEM-based MAR on scientific literacy and learning outcomes is still rarely done. The results of Yuliono and Sarwanto's research (2018) revealed that mobile augmented reality is very effective in improving the concept of science. MAR, as a learning medium, can be used so that students can process information obtained from the teachers (Kozma, 1994).

In addition to Mobile Augmented Reality, the learning process today needs to keep 
abreast of the times in the technological era, one of which integrates Science, Technology, Engineering, Mathematics (STEM). Research on STEM conducted by Ismail et al., (2016), found that the use of STEM-based virtual labs can increase student scientific literacy. Morrison, as quoted by Afriana, et al., 2016, stated that the benefits of STEM-based learning could make students able to solve problems, be innovators, independent, logical thinkers, and critical. STEM-based learning can build creativity and literacy that are needed to face the 21 st century. To face the era of global competition, Indonesia needs to prepare reliable human resources in STEM disciplines in quality and sufficient quantity (Firman, 2015). From the research findings, the use of a STEM-based virtual lab can increase students' scientific literacy.

Science literacy and science learning outcomes are assessed in the Program for International Student Assessment (PISA), one of the international studies designed and programmed by the Organization for Economic Cooperation and Development (OECD). PISA survey results reveal that the students' scientific literacy is in the lowest category. In 2009 Indonesia was on the 60th rank from 65 countries, in 2012 was on 64th rank from 65 countries, and in 2015 was on 63rd rank from 72 countries (PISA Results from PISA 2015 for Indonesia, 2016). The results of research conducted by Nurjanah, et al. (2017) at Majalengka Elementary School, Indonesia and Fazilla (2016) at the Almuslim University Elementary School Teacher Education, Indonesia shows that scientific literacy ability has not been reached optimally. This reported is caused by the application of learning approaches and the use of instructional media that are not optimal, especially practical tools (Adisendjaja and Romlah, 2009; Ismail et al., 2016).

Based on these problems, it is exciting to study the use of learning media that can help students in increasing scientific literacy and learning outcomes of science. The problems of this study are: (1) Does the STEM-based learning aided by mobile augmented reality affect the students' scientific literacy?; (2) does STEM-based learning assisted by mobile augmented reality effectively improve the student science learning outcomes?; (3) Is there a difference results of the students' scientific literacy and achievement between students who are taught using STEM-based learning assisted by mobile augmented reality and students who are taught applying conventional learning in science learning?

\section{Research Focus}

The study aimed at investigating: (1) the effectiveness of the application of STEM-based learning assisted by mobile augmented reality on the students' scientific literacy. (2) the effectiveness of the application of STEM-based learning assisted by mobile augmented reality on students' science learning outcomes. (3) the differences of the students' scientific literacy and achievement between the students who are taught using STEMbased learning assisted by mobile augmented reality and the students who are taught applying conventional learning in science learning.

\section{CONTEXT AND LITERATURE REVIEW}

The improvement of science learning quality can be increased through well science literacy ability and science learning achievement of the students. Scientific literacy is the main goal of science education about concepts, scientific principles, rules, theories, and 
inquiry skills. Most of the scientific literacy will become an experience and key success in science education (UNESCO, 2010). Science literacy is a way to involve and motivate students to be more effective in science learning and scientific work (Saribas, 2015). According to Paul De Hurd (DeBoer, 2000), science literacy is the skill understanding of science and its application for community needs. Science literacy concerned with how to understand, use, and reflect written text to achieve someone's goal in developing knowledge and potency in participating in a community (Kennedy et al., 2012). Science literacy cannot be separated from the essence of studying science itself, which relates to science learning achievement. States that science learning achievement is the mastery of someone toward knowledge and specific skills in a subject which is usually gained through tests or score given by teachers (Winkel, 2007). Learning achievement is the ability or skills owned by students (Azwar, 1998). A good learning achievement and science literacy cannot be separated from the learning approach and learning media used in the science learning process. One of the learning approaches that can improve learning achievement and science literacy is the STEMBased approach.

STEM is interdisciplinary learning to learn academic concepts accurately, which combines subjects in the real world in implementing science, technology, technique, and mathematics relating to school, community, work, and activities in the globalization era (Sahin, 2015). Brown et al. (2011) define STEM as meta discipline at the school level wherein science, technology, technique, and mathematics are taught in an integrated way of each subject. Dugger (2016) defines STEM as a learning approach needed to develop the 21st community era, which depends on technology. (National Research Council, 2014) Defines STEM into four parts; 1) science is the body of knowledge accumulating time to time from scientific investigation producing new knowledge. 2) Technology is all systems of a person, organization, knowledge, process, and tools, which in turn create things and operate them. 3) The technique is the body of knowledge about designing and creating things made by humans and a process to solve problems. 4) Mathematics is a study about patterns and relationships between total number and space.

Bybee (2013) states that STEM is a process of solving a problem using science and mathematics concepts in creating or designing a product called technology. The relationship between science, technique, technology, and mathematics is science gives way or tool to estimate the characteristics of things or materials through science concepts used in technique in solving practical problems producing a product called technology. Technology gives eyes and ears to science. Technology shows a close relationship in these four fields to be combined as an approach to study science. STEM is a learning approach accumulated from the knowledge of science, technology, engineering, and mathematics to solve problems in community life.

STEM-Based learning is believed can develop teacher's pedagogical competence, achieve affective and cognitive domain in science learning, increase students interest, create fascinating learning, and then students can solve problem when learning science (Rose et al., 2017, Williams, et al., 2015; Shahahali, et al., 2017: Christensen, et al.,2017, Manduca, et al, 2017). Jorge Martin et al. (2017) and Karagozlu \& Ozdamli 
(2017) find that the use of MAR in learning science can develop students' creativity and seen very useful because it can visualize the material concept tangibly. Therefore, the use of MAR as the media could support STEM-Based learning in learning science.

Boyles (Syawaludin et al., 2018) states that MAR combines virtual things into real three dimensions and projecting those virtual things in real-time. MAR can be used in education as learning media to increase students' motivation (Saidin et al., 2018), increase academic achievement, motivation, and student liveliness (Saltan \& Arslan, 2016). MAR can be described as a real-time combination of digital and physical information (Cabero \& Barroso, 2016), MAR is as a kind of technology which is more productive in education (Wu et al., 2012). Kamphuis et al., \& Coi (Byles, 2017) state that MAR considered as technology-based media used to explain science concepts effectively.

The use of MAR can be integrated into STEM-Based learning. Implementing media assisted STEM can push students to design, develop, and use technology, sharpen cognitive, manipulative, affective skills, and apply knowledge (Permanasari, 2016). STEM can be supported by using learning media in its learning process to improve science literacy and science learning achievement.

\section{METHOD}

In this study, a quasi-experimental method was used. It employed a posttest-only control group design (Gall, Gall, \& Borg, 2003). The research hypotheses were tested using multivariate analysis of variance (MANOVA) and using the t-test. This analysis to measure the size of the effect of the independent variables on the dependent variables by employing the formula proposed by effect size test using the formula proposed by Thailmer \& Cook (2002), with a low category (Es $\leq 0.2)$; enough (Es $\leq 0.8)$; and high (Es > 0.8). The research hypotheses were tested with the following procedures, namely:: 1) compiling a multivariate analysis of variance (MANOVA) table by calculating JP treatment, 2) calculating JP residue, 3) calculating total JP (corrected). The population of this study was all students at the four grade level of the Elementary School Teacher Program of Saint Paul Educational College Ruteng, Indonesia, in the 2018/2019 academic year. The population in the study was 516 students in 9 classes. Researching by involving all members of the population will cause its obstacles in conducting research. Therefore, this study was conducted on several samples in the population. The choice of class as a research sample uses random sampling techniques. By using this random sampling, two experimental classes and two control classes were chosen. Before determining the sample equality test is performed. The results of the analysis of the validity of scientific literacy instruments and test items of learning outcomes are very valid $(1.0>0.74)$ because CVR-hit $>$ CVR-table with CVR-table $=0.74$. Data analysis in this study used multivariate analysis of variance with the help of SPSS 16.0. The assessment of scientific literacy through the questions of scientific literacy is seen from the indicators of scientific literacy, namely scientific contexts, scientific knowledge, and scientific competencies (PISA 2015 Science Literacy Assessment Indicators). This research was conducted seven meetings by giving 12 numbers of scientific literacy questions and evaluating 30 scientific items. To determine the feasibility of learning used science attitude observation sheet with indicators of interest in science, Science 
Inquiry, and Sensitivity and Responsibility in the experimental class and the control class. The lecturers in the trial and control classes are science lecturers who have conducted training and socialization with the stages of learning and assessment of STEM-based learning assisted by mobile augmented reality.

\section{FINDINGS}

\section{Results of Science Literacy}

The results of the descriptive analysis of students' scientific literacy score of science learning treated through MAR assisted STEM-Based is displayed in table 1.

Table 1

Recapitulation of Science Literacy Score

\begin{tabular}{lll}
\hline Statistics & MAR assisted STEM-Based learning media & Conventional Learning \\
\hline & Experiment & Control \\
\hline Amount of Data & 87 & 88 \\
\hline Amount of Score & 3969 & 3683 \\
\hline Average Score & 76.99 & 58.70 \\
\hline Standard Deviation & 6.277 & 5.31 \\
\hline Variance & 39.401 & 29.46 \\
\hline
\end{tabular}

Table 1 shows science literacy score data of students who take science learning with learning using MAR-based STEM-based learning with indicators of scientific literacy questions in the dimensions of scientific contexts, scientific knowledge, and scientific compatibility. The average score of scientific literacy is obtained through three indicators of scientific literacy, namely scientific contexts, scientific knowledge, and scientific competencies producing different scores in the experimental class and the control class.

Table 2

Recapitulation of Science Literacy Score every dimension

\begin{tabular}{lll}
\hline Dimensions & Experiment & Control \\
\hline Scientific Contexts & 15.11 & 13.74 \\
\hline Scientific Knowledge & 15.28 & 14 \\
\hline Scientific Competencies & 15.23 & 13.802 \\
\hline
\end{tabular}

To visualy, each dimension of science literacy is displayed in histogram as shown in figure1.

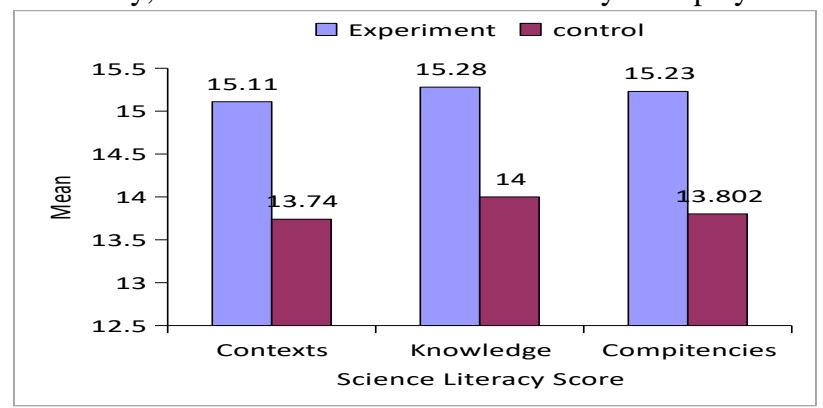

Figure 1

Average Literacy Score of three indicators namely Scientific Contexts, Scientific Knowledge, and Scientific Competencies in Learning Science 
To determine the feasibility of learning used science attitude observation sheet shown in Figure 2.

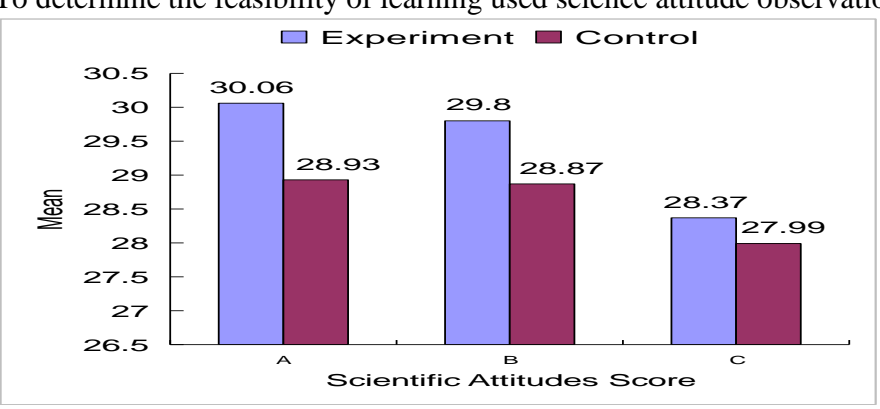

Figure 2

The average score of Indicator of scientific attitude dimension of students treated through MAR assisted STEM-Based and students attending conventional approach in science learning

Annotation: A: Science Interest; B: Science Inquiry; C: Sensitivity and Responsibility

Figure 2. obtained the average dimensions of the scientific attitude of students who take part in learning using MAR-based STEM-assisted media. Namely, science interest gained an average of 30.06, indicators of scientific inquiry using the scientific method had an average score of 29.80 , and indicators of sensitivity to the environment and responsibility obtained an average score of 28.37. The average dimensions of the scientific attitude of students who take learning with conventional learning namely; science interest gained an average of 28.93 , indicators of scientific inquiry using the scientific method had an average score of 28.87 , and indicators of sensitivity to the environment and responsibility obtained an average score of 27.99.

The results of the effect size test application of MAR-based STEM-based learning on science literacy indicate that the value of effect size $=0.5$ with enough categories. Effect size 0.5 is an effect size of three dimensions of scientific literacy, the scientific contexts, scientific knowledge, and scientific competencies. Shows that the application of MARbased STEM learning is quite effective in increasing the dimensions of scientific contexts, scientific knowledge, and scientific competencies in students.

\section{Learning Science achievements}

The data of science learning achievement of students treated through MAR assisted STEM-Based, and students attended a conventional approach to the cognitive process of applying conceptual knowledge, and analyzing procedural knowledge is shown in table 3 .

Table 3

Recapitulation Score on the Science Learning Achievement of Students

\begin{tabular}{lll}
\hline Statistics & MAR assisted STEM-Based Science Learning & Conventional Learning \\
\hline Class & Experiment & Control \\
\hline Amount of Data & 87 & 88 \\
\hline Number of Data & 2278 & 2168 \\
\hline Mean & 25.90 & 22.045 \\
\hline Standard Deviation & 3.555 & 3.51 \\
\hline Variance & 12.21 & 11.61 \\
\hline
\end{tabular}


Table 3 shows that the average score on the science learning achievement of students attending MAR assisted STEM-Based is very good, and the average score on the science learning achievement of students attending conventional learning is at enough level.

The results of the effect size test of the application of learning based on STEM-assisted MAR to the results of learning science shows the value of Es $=0.5$ so that it is considered sufficient because it is in the category of $0.31 \leq 0.8$.

The Difference Test Results of Science Literacy and Science Learning Science achievements of Experiments and Control Classes

The results of inferential statistic test on the difference of science literacy score and learning achievement of students attending MAR assisted STEM-Based and students attending conventional learning shown in table 4.

Table 4

Results of Test on Difference Science Literacy and Science Learning Achievement MultivariateTests ${ }^{\mathrm{b}}$

\begin{tabular}{lllllll}
\hline Effect & & Value & F & Hypothesis df & Error df & Sig. \\
\hline Science & Literacy \& & .099 & $9.471^{\mathrm{a}}$ & 2.000 & 172.000 & .000 \\
\cline { 2 - 7 } $\begin{array}{l}\text { Science } \\
\text { Learning } \\
\text { Achievement }\end{array}$ & Wilks's Trace & .901 & $9.471^{\mathrm{a}}$ & 2.000 & 172.000 & .000 \\
\cline { 2 - 7 } & Hotelling's Trace & .110 & $9.471^{\mathrm{a}}$ & 2.000 & 172.000 & .000 \\
\cline { 2 - 7 } & Roy's Largest Root & .110 & $9.471^{\mathrm{a}}$ & 2.000 & 172.000 & .000 \\
\hline
\end{tabular}

The results of the multivariate linear general analysis with the SPSS program on science literacy and science learning achievement variables show a significant number $<0.001$ with $\mathrm{F}=9.471$. The meaning there is a significant difference in science literacy and science learning achievement simultaneously between students attending MAR assisted STEM-Based and students attending conventional learning.

The results of the test of between-subjects effects about the difference of science literacy between students who attended MAR assisted STEM-Based, and students attended conventional learning showed $\mathrm{F}=18.059$ ( $\mathrm{p}<0.05$ ). Therefore $\mathrm{H} 0$ was rejected, meaning that there was a significant difference in science literacy between students who attended MAR assisted STEM-Based, and students attended conventional learning. The results of pairwise comparisons test showed that the average score difference in science literacy between students attending MAR assisted STEM-Based and students who attended conventional learning was 2.314. It means that the scientific literacy of students attending MAR assisted STEM-Based was significantly higher than the science literacy of students attending conventional learning.

The results of the test of between-subjects effects about the difference in science learning achievement between students who are attending MAR assisted STEM-Based and students attending conventional learning showed $F=12.953(\mathrm{p}<0.05)$. Therefore, H0 was rejected, meaning there was a significant difference in science learning achievement between students who are attending MAR assisted STEM-Based and students attending conventional learning. The results of pairwise comparisons test 
showed that the average difference score in science learning achievement between students attended MAR assisted STEM-Based, and students attending conventional learning was 1.874. It means that science learning achievement of students attending MAR assisted STEM-Based was significantly higher than the science learning achievement of students attending conventional learning.

\section{DISCUSSION}

The results of the descriptive analysis in students' science literacy after learning science treated through MAR assisted STEM-Based showed improvement in average score and categorized very well and good compared with conventional learning. The comparison of the average score of each dimension of science literacy, scientific contexts, scientific knowledge, and scientific competencies had its different score. Based on the average score achieved, the highest score was on the science competency aspect. The science competency aspect is the ability to use scientific evidence, identifying scientific issues, and explaining scientific phenomena. Those indicators found in instrument items of science literacy, which have a close relationship with students' science knowledge about the human transportation system. The results of this study are in line with the study conducted by Ismail et al. (2016), showing that learning through a STEM-Based virtual lab can improve science literacy in aspects of context, content, competency, and students' scientific attitude.

The average score for science literacy in the scientific attitude aspect had a different score for its indicator. Based on the scored achieved, students were more interested in science and inquiring science than responsibility and sensitivity to the environment. Science literacy is the understanding of science and its application for community needs (DeBoer, 2000:587). Learning science through MAR assisted STEM-Based showed the class is more active than learning science through the conventional approach. This result is supported by a study conducted by Rainey et al. (2019:2), emphasizing that a dynamic learning environment through STEM has a positive impact on students' science interest.

The result of the test between-subjects effects indicated that there was a significant difference in science literacy between students following MAR assisted STEM-Based learning approach and students following conventional learning approach. Science literacy of students following MAR assisted STEM-Based was significantly higher than the science literacy of students following conventional learning. The results of this study support a study conducted by Margot \& Kertler (2019); the implementation of STEM in learning supports the qualified curriculum, increases interest, and develops teachers' professionalism. STEM contributes to the strengthening of the pedagogical skills of students as being a teacher candidate (Carlisle \& Weaver, 2019). STEM-Based learning can improve concept understanding, individual investigation, and can solve problems related to science literacy (Utami et al., 2017).

The result of this study proves that MAR assisted STEM-Based in science learning has a positive impact on students' science literacy. There is a positive impact of MAR assisted STEM-Based on students' science literacy. Learning through MAR assisted STEMBased is a learning process insisting students be actively finding concepts through exploration activity using MAR media. 
The result of hypothesis testing about the difference of science literacy between students attending science learning treated through MAR assisted STEM-Based and students attending science learning through conventional approach indicated that there was a significant difference in science literacy achieved by them. Science literacy of students attending science learning treated through MAR assisted STEM-Based was significantly higher than students attending science learning through the conventional approach.

The result of descriptive analysis on students' science learning achievement after studying science treated through MAR assisted STEM-Based was increased on average score and categorized very good and enough compared to conventional learning. The result of the test of between-subjects effects indicated that there was a significant difference in science learning achievement between students attending science learning treated through MAR assisted STEM-based and students attending science learning using a conventional way. Science learning achievement of students joining science learning treated through MAR assisted STEM-Based was significantly higher than the science literacy of students conventionally attending science learning. The result of this study supports the study conducted by Griese et al. (2015), entitled "Refining Questionnaire-based Assessment of STEM Students Learning Strategies," which conclude that the STEM-Based learning technique can be used as a pedagogical model of teachers' professional development at Elementary School. Depending on the purpose of individual study, it is suggested to make a questionnaire for the metacognitive test. The characteristic of the previous assessment was separated from learning, and technically it is irrelevant. The latent position of metacognitive becomes clear in learning strategy and can be measured. Other types of data used are interview, videography, group discussions, class observations, portfolios, and can be used in further research of this study.

The findings of this study prove that science learning through MAR assisted STEMBased learning has a positive impact on students' science learning achievement. Furthermore, there is a positive impact of MAR assisted STEM-Based science learning on students' science learning achievement. The learning process using MAR assisted STEM-Based is learning that students are insisted on being active in acquiring concepts through exploration activity using MAR.

The result of hypothesis testing about the difference in science learning achievement between students following science learning treated through MAR assisted STEMBased and students following conventional learning indicated that there was a significant difference in result between the groups. Science learning achievement of students attending MAR assisted STEM-Based learning was significantly higher than the science learning achievement of students attending conventional learning.

The result of this study proves that science learning through MAR assisted STEM-Based contributes to a positive impact on students' science learning achievement. This positive impact is due to the process of MAR assisted STEM-Based science learning runs actively, and students have curiosity about concept, be able to solve problems, explaining, and argue on the basis of scientific evidence, be able to use technology through MAR media used, and give a report by interpreting data in quantitative and 
qualitative method. The MAR assisted STEM-Based science learning done is about the problem-solving process in science learning in developing science competency, science attitude, and understanding of science concepts.

MAR assisted STEM-Based learning can increase students learning achievement on procedural cognitive aspects and knowledge. The process of acquiring a science concept involves activities matching scientific steps or scientific process. In practicing of MAR media, it must follow the determined form. The scientific method will push students to develop scientific attitudes; interested in science issues, support science inquiry, responsible for environmental resources. The result of this study supports the study conducted by (Afriana et al., 2016), concluding that the implementation of PJBL integrated with STEM can improve science learning achievement and science literacy. The MAR assisted STEM-Based learning, which has been effectively developed to increase students' careers, improve interest in science, technology, mathematics, and science (Blotnicky, 2018). Consequently, the use of MAR assisted STEM-Based science learning can improve science literacy and students' science learning achievement.

\section{CONCLUSION}

Based on hypothesis testing, it can be concluded that MAR assisted STEM-Based learning in science learning influenced in science literacy and science learning achievement of students. There were some findings; (1) the results of scientific literacy are higher in students learning through MAR assisted STEM-Based rather than students learning through conventional way. (2) the results of learning achievement are higher in students learning through MAR assisted STEM-Based rather than students learning through conventional way. (3) Paired T-Test showed that MAR assisted Science Achievement, Science Literacy, Science, Technology, Engineering, Mathematics (STEM)-Based learning was more sophisticated than conventional learning in improving science literacy and students' learning achievement. The MAR assisted STEM-Based approach in science learning was more advanced than the conventional approach in science learning.

The results of this study recommend that the alternative approach of learning in science learning in science learning can be implemented through MAR-based STEM-based learning. Before carrying out learning first, there is a tutorial on the development of mobile augmented reality applications on the material taught according to the time of learning. Teachers and lecturers, especially for STEM-oriented education, should pay attention to four main things, namely, learning material and resources, learning activities or activities, learning models and approaches that are collaborated with STEM, and the implementation of evaluation through authentic assessment.

\section{ACKNOWLEDGEMENT}

My deep appreciation should go to Prof. Dr. I Wayan Sadia, M. Pd, Prof. Dr. Ni Ketut Suarni, M. S., Kons, and Prof. Dr. I Wayan Suastra, M. Pd, for their guidance and support. I also appreciate Fr. Yohanes Servatius Boylon, MA, the Head of STKIP Santu Paulus Ruteng for his support in my research. My special appreciation also should go to the Head of PGSD program and all lecturers of the PGSD program of STKIP Santu Paulus Ruteng for their moral supports in completing my research. 


\section{REFERENCES}

Ardianto, D., \& Rubini, B. (2016), Literasi Sains dan Aktivitas Siswa Pada Pembelajaran IPA Terpadu Tipe Shared. Unnes Science Education J, 5(1), 1167-1174.

Nurjanah, A., Sudin, A., \& Sujana, A. (2017). Literasi Sains dalam Pembelajaran PBL (Penelitian Preexperimental terhadap peserta didik kelompok atas, tengah, dan bawah SDN Waringin II dan SDN Palasah I di Kecamatan Palasah Kabupaten Majalengka pada Materi Energi Panas). Jurnal Pena Ilmiah Sumedang. 2(1), 581-590.

Afriana, J., Permanasari, A., \& Fitriani, A. (2016). Penerapan Project Based Learning Terintegrasi STEM untuk Meningkatkan Literasi Sains peserta didik Ditinjau dari Gender. Jurnal Inovasi Pendidikan, 2(2), 202-212

Adisendjaja, Y. H., \& Romlah, O. (2009). Peranan Praktikum Dalam Mengembangkan Keterampilan Proses dan Kerja Laboratorium. Makalah dipresentasikan pada pertemuan Musyawarah Guru Mata Pelajaran Biologi Kabupaten Garut, Jawa Barat.

Brown, R. et al. (2011). Understanding STE: Current Perception. Journal Technology and Engineering Teacher, 70, 5-10.

Bybee, R. W. (2013). The case for STEM education: Challenges and opportunities. Arlington: National Science Teachers Association (NSTA).

Boyles, B. (2017). Virtual reality and augmented reality in education. Papper (United States Military Academy, West Point, NY). 2:1-9.

Chiappetta, E. L., \& Alfred, T. C. (1994). Science instruction in the middle and secondary schools. New York: Macmillan Publishing Company.

Christensen, R. R., Knzeke, G., \& Tyler-Wood, T. (2015). Alignment of hands-on STEM engagement activities with positive STEM dispositions in secondary school students. Journal of Science Education and Technology, 24(6), 898-909

Carlisle, D. L., \& Weaver, G. C. (2019). STEM education centers: catalyzing the improvement of undergraduate STEM education. Int J of STEM Education, 5, 42-52

Cabero, J., \& Julio, B. J. (2016). The educational possibilities of augmented reality. New Approaches in Educational Research, 5, 44-50

Dugger, W. E. (2016). ITEEA Technology and engineering bring STEM to Life. (XXII Int Conference on Technological Education in Schools, Colleges, and Universitas, Moscow, Russia. 1:1-43.

Firman, H. (2015). Pendidikan Sains Berbasis STEM: Konsep, Pengembangan, dan Peranan Riset Pascasarjana. Seminar Nasional Pendidikan IPA dan PKLH, 1, 1-9.

Fazilla, S. (2016). Kemampuan Literasi Sains Mahapeserta didik PGSD pada MAta Kuliah Konsep Dasar Sains. Jurnal PGSD, 3, 22-28.

Gall, M., Borg, W. R., \& Gall, J. P. (2003). Educational research. USA: Pearson.

Griese, B., Lehmann, M., \& Roesken-Winter, B. (2015). Refining questionnaire-based assessment of STEM students learning strategies. International Journal of STEM Education, 2, art.2. 
Howe, A. C., \& Jones. L. (1993). Engaging children in science. New York: Maxwell Macmillan International.

Hennies, N. Ralph, M. A. L., Kempkes, M., Cousins, J. N., \& Lewis, P. A. (2016). Sleep spindle density predicts the effect of prior knowledge on memory consolidation. The Journal of Neuroscience, 36(13), 3799-3810.

Ismail, I, Permanasari, A., \& Setiawan, W. (2016) Efektivitas Virtual Lab Berbasis STEM dalam Meningkatkan Literasi Sains Siswa dengan Perbedaan Gender. Jurnal Pendidikan IPA Indonesia, 3(2), 106-124

Ismail, I. M. (2015). Pengaruh Bentuk Penilaian Formatif Terhadap literasi sains IPA Setelah Mengontrol Pengetahuan Awal Siswa. Lentera Pendidikan Jurnal Ilmu Tarbiyah dan Keguruan, 15(2), 1-8.

Kozma, R. B. (1994). The influence of media on learning: The debate continues. SLMQ, 22(4), 1-9

Karagozlu, D., \& Ozdamli, F. (2017). Student opinions on mobile augmented reality application and developed content in science class. TEM Journal, 6(4), 666-670.

Margunayasa, I. G., Nyoman, D., Marhaeni, A. A. I. N., \& Wayan, S. I. (2019). The effect of guided inquiry learning and cognitive style on science learning achievement. International Journal of Instruction, 12(1), 737-750

Margot, K. C., \& Kettler, T. (2019). Teachers' perception of STEM integration and education: a systematic literature review. International Journal of STEM Education, 6, art.2.

Manduca, C. A., Iverson, E. R., Luxenberg, M., Macdonald, R. H., McConnell, D. A., Mogk, D. W., \& Tewksbury, B. J. (2017). Improving undergraduate STEM education: The efficacy of discipline-based professional development. Science Advances, 3(2), e1600193.

Martin-Gutierrez, J., Mora, C. E., Anorbe, B., \& Gonzalez-Marrero, A. (2017). Virtual Technologies Trends in Education. EURASIA Journal of Mathematics Science and Technology Education. 13(2), 469-486.

Mahendra, E. (2007). Pengaruh Pendekatan Kontekstual dan Gaya Berpikir. Jurnal Ilmiah Pendidikan dan Pembelajaran. 3:583-606.

National Research Council. (2014). Status, Prospects, and an Agenda for Research. The National Academies of Science.

PISA. (2016). Results from PISA 2015 for Indonesia. OECD.

Permanasari, A., (2016). STEM Education: Inovasi dalam Pembelajaran Sains. Prosiding Seminar Nasional Pendidikan Sains (SNPS), 2, 23-34.

Rose, M. A., et al. (2017). Status of elementary teacher development: Preparing elementary teachers to deliver technology and engineering experiences. Journal of Technology Education, 28(2). https://doi.org/10.21061/jte.v28i2.a.1. 
Rainey, K., Dancy, M., Mickelson, R., Stearns, E., \& Moller, S. (2019). A descriptive study of race and gender differences in how instructional style and perceived professor care influence decisions to major in STEM. International Journal of STEM Education. 6, art.6.

Saltan, F. \& Arslan, O. (2016). The use of augmented reality in formal education: A scoping review. EURASIA Journal of Mathematics Science and Technology Education. 13(2), 503-520.

Sahin, A. (Ed.). (2015). Practice-based model of STEM teaching STEM students on the stage $(S O S)^{T M}$. Houston, USA: Sense Publisher.

Sadia, I W. (2014). Model-model Pembelajaran Sains Konstruktivistik. Yogyakarta: Graha Ilmu.

Syawaludin, R. A. (2018). Permainan Mobile Augmented reality Berbasis Lokasi Untuk Pengenalan Kehidupan Kampus Bagi Mahasiswa Baru Fakultas Ilmu Komputer Universitas Brawijaya. Jurnal Pengembangan Teknologi Informasi dan Ilmu Komputer, $2,1-9$

Shahali, E. H. M., Halim, L., Rasul, M. S., Osman, K., \& Zulkifeli M. A. (2017). STEM learning through engineering design: Impact on middle secondary students' interest towards STEM. EURASIA Journal of Mathematics Science and Technology Education, 13(5), 1189-1211

Thalheimer, W., \& Cook, S. (2002). How do calculate effect sizes from published research: A simplified methodology. Retrieved from https://www.bwgriffin.com/gsu/courses/edur9131/content/Effect_Sizes_pdf5.pdf.

Utami, I. S., Septiyanto, R. F., Wibowo, F. C., \& Suryana, A. (2017). Pengembangan STEM-A (Science, Technology, Engineering, Mathematics, And Animation) Berbasis Kearifan Lokal Dalam Pembelajaran Sains. Jurnal Ilmiah Pendidikan Fisika AlBiRuNi, 6(1), 2303-1832.

Williams, C. T., Walter, E., Henderson, C. R., \& Beach, A. (2015). Describing undergraduate STEM teaching practices: a comparison of instructor self-report instruments. International Journal of STEM Education, 2, 1-16

Winkel, W. S. (2007). Psikologi Pengajaran. Mehdi Abad: Jurusan Ilmu Pendidikan Fakultas Keguruan dan Ilmu Pendidikan Universitas Sanata Darma, Yogyakarta.

Wu, H-K., Lee, S. W-Y., Chang, H-Y., \& Liang, J-C. (2013). Current Status, opportunities, and challenges of augmented reality in education. Computers \& Education, 62, 41-49.

Yuliono, T., Sarwanto, \& Rintayati, P. (2017). Kefektifan Media Pembelajaran Augmented reality Terhadap Penguasaan Konsep Sistem Pencernaan Manusia. Jurnal Pendidikan Dasar, 2, 65-84. 